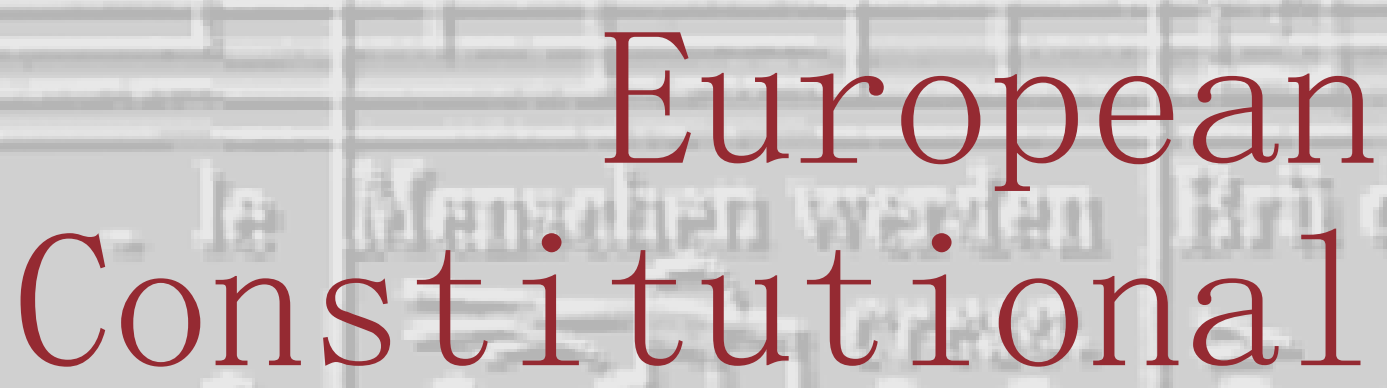

\title{
Law Review
}

\section{I 5 VOLUME I I ISSUE 2}

\section{Contributions}

Monika Szwarc, Davide Paris, Ada Paprocka and Michał Ziółkowski, François-Xavier Millet, Roberto Mastroianni and Amedeo Arena, Tobias Lock, Jasper Krommendijk, and Raf Geenens and Stefan Sottiaux

\section{Subjects}

The future of the European Union's accession to the European Convention on Human Rights; Advisory opinions under Protocol No. 16 of that Convention; Belgium: sovereignty and direct democracy under its Constitution; THE CourT of Justice of THE European Union and the role of the Charter in its case-law; its ruling revealing the difficulty of choosing a legal basis without the pillars; its ruling on freedom of movement of lawyers; its ruling on constitutional courts as guardians of EU fundamental rights; and The European Court of Human Rights decides on the burqa ban in France 


\section{BOARD OF EDITORS}

Leonard F.M. Besselink, co-editor-in-chief Professor of European Constitutional Law, University of Amsterdam

Monica Claes, co-editor-in-chief

Professor of European and

Comparative Constitutional Law,

Maastricht University

Jan-Herman Reestman, co-editor-in-chief

Associate Professor of Public Law, University of Amsterdam

\section{W.T. Eijsbouts}

Emeritus Professor of European Constitutional Law and its History, University of Amsterdam and Emeritus Professor of European Law, Leiden University

John W. Sap

Professor of European Union Law, Open

University in the Netherlands and Associate

Professor of European Union Law,

VU University Amsterdam

\section{Thomas Beukers}

European University Institute, Florence

Jan Komárek

London School of Economics

Gerhard van der Schyff

University of Tilburg

Junior editors

Geerten Boogaard

Leiden University

Thomas A.J.A. Vandamme

University of Amsterdam

Jeremy B. Bierbach, production editor

Attorney at law, Franssen Advocaten, Amsterdam

Bastian Michel, managing editor

Ph.D. candidate, University of Amsterdam

Special language adviser

Russell E.M. Lawson

Oxford

\section{BoARd of Advisors}

Andreas Auer

Professor emeritus of public law, Universities of

Zurich and Geneva

Paul Craig

Professor of English law, St. John's College, Oxford

Gráinne de Búrca

Professor of law, New York University

School of Law

Bruno De Witte

Professor of European Union law, European

University Institute, Florence; Professor of

European Union law, Maastricht University

Olivier Duhamel

University Professor at IEP (Sciences Po), Paris

Spyridon Flogaitis

Professor of administrative law, University of Athens

Jörg Gerkrath

Professor of European law, University of

Luxembourg

P.J.G. Kapteyn

Former judge in the ECJ

Tim Koopmans

Former judge in the ECJ and Advocate General at the Hoge Raad (Supreme Court of the Netherlands), The Hague

Rick Lawson

Professor of European Law, Leiden University

Koen Lenaerts

Judge in the ECJ and professor of European law,

University of Leuven

\section{Ingolf Pernice}

Professor of public law and of international and European law, Humboldt University, Berlin

Jit Peters

Professor emeritus of public law, University of Amsterdam

Lucas Prakke

Professor emeritus of comparative constitutional law, University of Amsterdam

Sacha Prechal

Judge at the ECJ and Professor of international and European institutional law, University of Utrecht

W.H. Roobol

Professor emeritus of European history,

University of Amsterdam

\section{Dominique Rousseau}

Professor of public law, Université Paris 1

Panthéon-Sorbonne

András Sajó

Judge of the European Court of Human Rights

Mirostaw Wyrzykowski

Professor of constitutional law at Warsaw

University

Peter G. Xuereb

Professor of European and comparative law, University of Malta

Jiri Zemánek

Professor of European Union Law, Charles University, Prague, Judge in the Czech

Constitutional Court 


\section{EUROPEAN CONSTITUTIONAL LAW REVIEW \\ 20 I 5 Volume i I IsSue 2}

\section{Contents}

\section{Editorial}

On Courts of Last Resort and Lenders of Last Resort 227

Articles

Tobias Lock - The future of the European Union's accession to the European Convention on Human Rights after Opinion 2/13: is it still possible and is it still desirable? 239

Ada Paprocka \& Michał ZıóŁKowski - Advisory opinions under Protocol No. 16 to the European Convention on Human Rights 274

Raf Geenens \& Stefan Sottiaux - Sovereignty and Direct Democracy: Lessons from Constant and the Belgian Constitution 293

Jasper Krommendijk - Principled Silence or Mere Silence on Principles? The Role of the EU Charter's Principles in the Case Law of the Court of Justice 321

\section{Case Notes}

Monika Szwarc - The pillars of the European Union still exist? European Court of Justice (Grand Chamber), Judgment of 6 May 2014, Case C-43/12, Commission v European Parliament and Council 357

Roberto Mastroianni \& Amedeo Arena - Free movement of lawyers and the Torresi judgment: a bridge too far? - European Court of Justice, Grand Chamber Judgment of 17 July 2014, Joined Cases C-58/13 and C-59/13 Angelo Alberto Torresi and Pierfrancesco Torresi v Consiglio dell'Ordine degli Avvocati di Macerata 373

Davide PARIs - Constitutional Courts as Guardians of EU Fundamental Rights? Centralised Judicial Review of Legislation and the Charter of Fundamental Rights of the EU - European Court of Justice (Fifth Chamber), Judgment of 11 September 2014, Case C-112/13, $A \vee B$ and others 389

François-Xavier Millet - When the European Court of Human Rights encounters the face A case-note on the burqa ban in France - European Court of Human Rights, Judgment of 1 July 2014, Case No. 43835/11, S.A.S. v France 408 


\section{Editorial Policy \& Guidelines for Contributors}

The journal is edited in the Hogendorpcentre for European Constitutional Studies, a Jean Monnet Centre of excellence. This Centre is based in the University of Amsterdam. Published three times a year. In the tradition of the Hogendorpcentre, the European Constitutional Law Review (EuConst) follows the classical approach of constitutionalism, to discuss EU law's developments as well as comparative public law of the member states, political and constitutional theory and history. The journal is a platform for scholarly discussion of European constitutional events and evolution. It is open to contributions in this field from any country in the world and from any discipline. These contributions should satisfy as to substance, apart from the common scholarly criteria, two specific conditions, to a) have a distinctly European relevance and b) include a reference to and discussion of legal aspects involved.

\section{Submitting an article, case note or book review}

The editors of the European Constitutional Law Review are happy to receive contributions on relevant subjects at any time. Before submitting, authors should ensure that their contribution falls within the scope of EuConst as stated above.

Articles, case notes and book reviews can be sent by email to euconst@uva.nl. Manuscripts should be attached in Microsoft Word format (and not, specifically, in PDF format) to enable editing, anonymisation and comments. EuConst has an exclusive submission policy. Authors are required to state clearly, when submitting, that their contribution is not under consideration elsewhere.

Authors of article contributions are asked to aim for a length of no more than 10,000 words (including footnotes). Case notes and book reviews should not exceed 5,000 words. Upon request, the editors will consider whether relaxation of these limits is justified.

All submissions must be written in good English. Authors who are uncertain whether their English is of sufficient quality, should have their manuscript reviewed and edited by a native speaker with a background in law.

\section{Copyright, licence to publish and open access policy}

Contributors retain copyright. By submitting to EuConst, authors agree that upon acceptance of their contribution they will grant an exclusive licence to publish by signing and returning the appropriate Licence Form. Authors can make their contributions available through academic repositories. For more information, including terms and conditions of publication and authors rights of reuse, see $<$ journals.cambridge.org/EuConst_CTF>.

\section{Revisions and house style}

Accepted contributions will be edited, linguistically and substantively, subject to authors' approval. Authors should ensure that their submissions conform to the house style. A style sheet is available on the journal website, <journals.cambridge.org/euconst >.

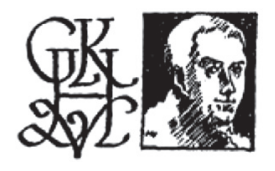

The G.K. van Hogendorpcentre for European Constitutional Studies, short: Hogendorpcentre, is a Jean Monnet centre of excellence at the University of Amsterdam. Founded in 1996, it promotes research and course development in the field of European Constitutional Studies, bringing together the disciplines of constitutional (including comparative) law, history, political theory. Gijsbert Karel van Hogendorp, 1762-1834, is the auctor intellectualis of the Dutch Kingdom's first constitution, of 1814. 